\title{
Leaf and whole plant transpiration in honey mesquite fol- lowing severing of lateral roots
}

\author{
R.J. ANSLEY, P.W. JACOBY, AND R.A. HICKS
}

\section{Abstract}

This study examined water loss by fully grown honey mesquite (Prosopis glandulosa var. glandulosa Torr.) trees at 2 levels of resolution, the whole plant (canopy) and the individual leaf. Trees were manipulated by severing lateral roots during winter dormancy. Leaf transpiration and photosynthesis were measured in root-severed and unsevered (control) trees for 2 growing seasons following treatment. An empirical model which integrated leaf transpiration, whole plant leaf area, and influence of shading within the canopy on leaf transpiration was used to calculate daily water loss from individual trees. During the first growing season leaf abscision occurred on root-severed, but not control trees, in early July, resulting in a $50 \%$ reduction in whole plant leaf area. Following abscission, transpiration and photosynthesis of remaining leaves on root-severed trees were significantly greater than on control trees from July through September. Because of increased transpiration of remaining leaves on root-severed trees, daily water loss per tree was not significantly different between root-severed and similar-size control trees before or after leaf abscission. No differences in leaf or canopy transpiration were found between root-severed or unsevered honey mesquite during the second growing season. Daily water loss per tree ranged from 30 to 75 liters during the study. These responses illustrate that water loss from mesquite may be regulated by various combinations of stomatal control and adjustment of transpirational surface area.

Key Words: leaf area, photosynthesis, phreatophyte, stomatal conductance, water potential, water relations

Honey mesquite (Prosopis glandulosa Torr.) inhabit a variety of arid and semiarid environments in the southwestern USA and Mexico. In some regions, such as the Sonoran desert of California or the southern High Plains near Lubbock, Texas, mesquite have been described as drought-avoiding phreatophytes which utilize deep ground water via extensive taproots (Mooney et al. 1977, Thomas and Sosebee 1978, Levitt 1980). These phreatophytic mesquite also exhibit mechanisms of drought tolerance, including seasonally changing stomatal sensitivity and osmotic adjustment (Nilsen et al. 1981, Nilsen et al. 1983).

In regions where deep groundwater is minimial, mesquite often appear to be less than fully phreatophytic. These plants have developed an extensive system of lateral roots (Ludwig 1977, Heitschmidt et al. 1988) and respond rapidly to precipitation (Ansley et al. 1989). The degree to which lateral roots influence water

\footnotetext{
Authors are postdoctoral research associate and professor, Texas A\&M University Agricultural Experiment Station, P.O. 1658, Vernon, Texas 76384; and graduate assistant, Texas A\&M University, College Station, Texas.

Published with the approval of the director, Texas Agricultural Experiment Station as TA-25359. This research was funded in part by a grant from the Texas Water Development Board (Contract IAC 0940), Austin, Texas; the USDA Soil Conservation Service, Ft. Worth, Texas; and E. Paul and Helen Buck Waggoner Foundation, Vernon, Texas.

The authors wish to acknowledge Dave Price, Don Wilhoite, Tom Wright, and Steve Dowhower for assistance in data collection, Kathy Young for computer programming, and Fay Smith for typing the manuscript. We thank Rod Heitschmidt Keith Owens, Bill Dugas, and David Briske for reviewing various drafts of this manuscript.

Manuscript accepted 26 January 1991.
}

relations of honey mesquite is not fully understood but may relate to the amount of available groundwater (Ansley et al. 1990).

Most studies of woody plant water relations in semiarid environments have been based on measurements of the individual leaf (Schulze and Hall 1982). Increasingly there is a need to relate whole plant responses to environmental changes (Pook 1985, Nilsen et al. 1987, Meinzer et al. 1988). It is not known whether leaf responses parallel whole plant responses under all conditions since microclimatic variation within the canopy influences leaf responses (Schulze et al. 1985, Caldwell et al. 1986, Gold and Caldwell 1989, Hinckley and Ceulemans 1989). This study was designed to determine water loss by honey mesquite at 2 levels of resolution, the whole plant and the individual leaf. The study complements earlier research which examined the influence of site on mesquite rooting strategies and water use (Ansley et al. 1990).

\section{Materials and Methods}

\section{Study Area}

Research was conducted on the Wagon Creek Spade Ranch located $16 \mathrm{~km}$ north of Throckmorton, Texas, in the Rolling Plains ecological region of north central Texas $\left(99^{\circ} 14^{\prime} \mathrm{W}, 33^{\circ} 20 \mathrm{~N}\right.$; elevation $450 \mathrm{~m}$ ). Soils on the study site are of the Nuvalde series (fine-silty, mixed, thermic family of typic Calcuistolls). Average annual precipitation is $624 \mathrm{~mm}$, which is distributed bimodally with peak rainfall periods in May and September. Average frostfree period is 220 days. Vegetation at the site is a mixture of mid-and shortgrasses with a 35\% canopy cover overstory of mesquite which, to our knowledge, had never been manipulated by human control practices. Tree density is about $300-400$ plants per ha. Mesquite growth form is erect and few-stemmed with the diameter of basal trunks on many of the plants in excess of $30 \mathrm{~cm}$ and heights in excess of $5 \mathrm{~m}$. Dominant perennial herbaceous species are sideoats grama (Bouteloua curtipendula [Michx.] Torr.), buffalograss (Buchloe dactyloides [Nutt.] Engelm.), and Texas wintergrass (Stipa leucotricha Trin. and Rupr.).

\section{Treatment Installation}

Six trees were selected for the study on the basis of uniformity of size and shape. Average height, canopy volume, and basal stem diameter (at $10 \mathrm{~cm}$ above ground) were $3.7 \mathrm{~m}, 25.8 \mathrm{~m}^{3}$, and $0.2 \mathrm{~m}$, respectively. The trees occurred in open areas so that shading from adjacent larger trees was not a factor except at sunrise and sunset. In January 1986, a vertical trench $3 \mathrm{~m}$ deep was cut around each of 3 trees roughly $1 \mathrm{~m}$ beyond the lateral perimeter of each canopy. The soil wall on the tree side of the trench was wrapped with 2 layers of 6 mil plastic, and a fiberglass sheet was attached to the upper $0.5 \mathrm{~m}$ of the plastic barrier before refilling the trench. The fiberglass sheets extended $20 \mathrm{~cm}$ above the surface to prevent overland flow of water from entering or leaving the containerized area. These trees are referred to as "root-severed". The 3 trees with intact root systems are referred to as "controls". Root barriers were installed during winter dormancy (i.e., leaves were abscised), 3 months prior to mesquite budbreak. Precipitation was measured at the site with a tipping-bucket rain gauge. 


\section{Leaf Measurements}

Leaf transpiration (E) and net photosynthesis (A) were measured monthly from April to September, 1986-1987, using a closed chamber system ${ }^{1}$. Duration of each measurement was 40 seconds. Air flow rate in the chamber was varied to maintain chamber relative humidity $(\mathrm{RH})$ at ambient $\mathrm{RH}$ levels ( \pm percentage points). Measurements were made at 2-hour intervals during each sample day on 2 leaves on the sunlit aspect of each tree canopy. Leaves were selected from the canopy perimeter about 1.5 to $2 \mathrm{~m}$ above ground. Approximately $5-9 \mathrm{~cm}^{2}$ (1 side) leaf area was enclosed in the chamber during each reading. Photosynthetically active radiation (PAR, 400 to $700 \mathrm{~nm}$ ) was determined at the position on the canopy perimeter where $E$ and $A$ were measured using a quantum sensor ${ }^{2}$ which was mounted to the leaf chamber. Sampling was conducted on clear or mostly clear days.

Predawn leaf petiole xylem water potential (predawn leaf $\Psi$ ) was measured on each $E$ and $A$ sample date. Two leaves were excised from the center of each canopy and measurements were made immediately with a Scholander pressure bomb (Turner 1981).

\section{Whole Plant Leaf Area Determination}

Whole plant leaf area (WPLA) was estimated for the control trees on 12 June and $23 \mathrm{July} 1986$ by clipping three $1.5-\mathrm{cm}$ diameter $( \pm 0.3 \mathrm{~cm})$ branches (as subsamples) from each of 4 or 5 nonexperimental trees growing near the control trees. All leaves were harvested and total leaf area per subsample was determined with an area meter. Leaf area per branch (1 leaf side) averaged $0.43 \mathrm{~m}^{2}$ on 12 June and $0.40 \mathrm{~m}^{2}$ on $23 \mathrm{July}$, representing a $7 \%$ reduction during the interval. Coefficient of variation in leaf area among trees and among subsamples on each date was less than 14 and $17 \%$, respectively. WPLA of each control tree was determined by counting the number of $1.5-\mathrm{cm}$ diameter branches which supported foliage, and multiplying that by the leaf area per branch that was determined from the nonexperimental trees.

WPLA of root-severed trees was determined in a similar manner as the control trees on 12 June 1986, when foliage appeared similar to that of adjacent nonexperimental trees. However, by 23 July, foliage declined on root-severed trees such that it was no longer visually comparable to that of nonexperimental trees. Thus, the technique employed to assess WPLA of control trees on this date was not considered valid for estimating WPLA of root-severed trees. Therefore, on 23 July foliage reduction of root-severed trees was visually estimated by 6 individuals after comparing growth to that of adjacent nonexperimental trees. Average percent reduction in foliage on root-severed trees when compared to adjacent trees on this date was $42.8($ s.e. $=5.3, n=3)$. To estimate foliage reduction on root-severed trees from $12 \mathrm{June}$ to $23 \mathrm{July}$, an additional $7 \%$ was added to the $\mathbf{4 2 . 8}$ value to account for the decline in foliage on control trees during this interval ( $7 \%$ was derived from the 0.43 to $0.40 \mathrm{~m}^{2}$ decline in leaf area per branch).

In 1987, WPLA was estimated monthly from mid-May to midSeptember using a digital image analysis procedure based on photographs of the trees (Ansley et al. 1988). Side-view black and white photographs of entire canopies of experimental and nonexperimental trees were obtained from fixed points $20 \mathrm{~m}$ from each tree and using a 300-mm telephoto lens. Within 3-4 days after each photography date, nonexperimental trees were completely harvested. Total leaf area per tree was determined by obtaining total leaf weight (oven dry at $80^{\circ} \mathrm{C}$ ) and establishing weight:area regressions (using subsamples of the total leaf mass and an area meter). Tree images were outlined with a marker and area within the outline was determined using a tablet digitizer and computer software ${ }^{3}$. Regressions between digital values of the images and WPLA of harvested trees were established for each sample date (Table 1) and used to predict WPLA of the experimental trees. WPLA values obtained using the photographic method did not differ significantly $(P<0.05)$ from those obtained by branch harvesting method,

Table 1. Regression equations between leaf area and digital values of side-view images of trees harvested on several dates in 1987.

\begin{tabular}{lcllc}
\hline \hline Date & $\begin{array}{r}\text { No. trees } \\
\text { harvested }\end{array}$ & Regression equation & $r^{2}$ & $\mathrm{~F}$ \\
\hline 11 May/19 Sept. ${ }^{1}$ & 6 & $\mathrm{Y}=3.60 \mathrm{x}-1.69^{2}$ & .98 & $190^{* * 3}$ \\
11 June & 6 & $\mathrm{Y}=3.15 \mathrm{x}-1.80$ & .95 & $84^{* *}$ \\
10 July & 6 & $\mathrm{Y}=2.55 \mathrm{X}-0.25$ & .84 & $21^{*}$ \\
07 August & 6 & $\mathrm{Y}=2.30 \mathrm{x}-0.31$ & .76 & $13^{*}$ \\
\hline
\end{tabular}

'Dates with similar regressions were pooled.

$2 \mathrm{Y}=$ Whole plant leaf area (one leaf side; $\mathrm{m}^{2}$ ); $\mathrm{X}=$ digital values of canopy images (units are $\mathrm{m}^{2}$ side-view area of canopy).

${ }^{3 *}=$ significant at $P \leq .05 ; * *=$ Significant at $P \leq .01$.

as described earlier, when nonexperimental trees were used to compare the 2 methods in 1987.

\section{Whole Plant Transpiration}

A multilayer model was developed to estimate daily whole plant transpiration (WPE). Estimates were based on an integration of $E$, WPLA, and a series of empirically derived coefficients, termed transpiration coefficients (TC), designed to account for variation of $E$ as influenced by shading within layers of the canopy (Schulze et al. 1982, Landsberg and McMurtrie 1984, Caldwell et al. 1986, Raupach and Finnigan 1988). A "day" in the model was defined as the 10-hour period from 1 to 11 hours post sunrise (HPS) in 1986 and 2 to 12 HPS in 1987. Each day in the model was segmented into five 2-hour intervals (i) so that:

where,

$$
\text { WPE }=\Sigma E_{2}
$$

$$
\begin{aligned}
& \text { WPE = Daily whole plant transpiration }\left(\mathrm{kmol} \mathrm{H}_{2} \mathrm{O} \text { tree }^{-1}\right. \\
& \text { day }^{-1} \text { ), and } \\
& E 2_{\mathrm{ij}}=\text { Two-hour whole plant transpiration ( } \mathrm{mol}_{2} \mathrm{O} \\
& \text { tree }^{-1} 2 \mathrm{hr}^{-1} \text { ) at 2-hour interval } \mathrm{i} \text { (for } \mathrm{i}=1 \text {...n, } 1=1 \text { - } \\
& \text { 3HPS; 2=3-5 HPS, 3=5-7 HPS, 4=7-9 HPS, 5= } \\
& \text { 9-11 HPS), on date } j \text { (add } 1 \text { to HPS values for } \\
& \text { 1987). }
\end{aligned}
$$

To determine TC values, once during spring and again in midsummer of both years (4 sample periods total), 1 control tree was selected for intensive sampling in which $E$ was measured within 4 diurnally changing shade layers within the canopy. Each layer was visually estimated to contain 25\% of WPLA. Boundaries of each layer were oriented perpendicularly to solar angle during each sample period. Six measurements of $E$ and PAR were made per layer during each sample period. Sample periods coincided with pre-defined 2-hour intervals. TC's within the 3 shaded layers (L2-L4) were expressed relative to the most sunlit layer (L1) so that:

$$
\begin{aligned}
& \mathrm{TC}_{\mathrm{B}}=\mathrm{E}_{\mathrm{s}} / \mathrm{E}_{\mathrm{o}} \\
& \text { where, } \\
& \text { TC }=\text { Transpiration Coefficient at shade layer } \mathrm{s} \text {, } \\
& \text { E. }_{\text {s }} \quad \text { Leaf transpiration }\left(\mathrm{mmol} \mathrm{m} \mathrm{m}^{-2} \mathrm{~s}^{-1}\right) \text { at shade layer } \\
& \mathrm{s} \text {, and } \\
& \text { E。 = Leaf transpiration }\left(\mathrm{mmol} \mathrm{m}^{-2} \mathrm{~s}^{-1}\right) \text { at the most } \\
& \text { sunlit layer, } \mathbf{L} 1 .
\end{aligned}
$$

To determine the influence of canopy shading on PAR, radiation coefficients $(R C)$ were determined in a similar manner as transpiration coefficients, so that: 
where,

RC. = Radiation Coefficient at shade layer s,

PAR $_{\mathbf{a}}=$ PAR $\left(\mathrm{uE} \mathrm{m}^{-2} \mathrm{~s}^{-1}\right)$ at shade layer $\mathrm{s}$, and

PAR $_{0}=$ PAR $\left(\mathrm{uE} \mathrm{m}^{-2} \mathrm{~s}^{-1}\right)$ at the most sunlit layer, $\mathrm{Ll}$

When averaged over all 4 sample periods, $E$ was reduced by 17,26 , and $38 \%$ (i.e., $\mathrm{TC}=0.83,0.74$, and 0.62 ) in shade layers $\mathrm{L} 2, \mathrm{~L} 3$, and L4, respectively. PAR was reduced by 47,68 , and $82 \%$ (i.e., $R C=$ $0.53,0.32$, and 0.18 ) in shade layers $L 2, L 3$, and $L 4$, respectively.

Values for $E 2_{i j}$ were determined by integrating $E$ and $T C$ values so that for $i=1 . . .5$ on date $j$,

$$
\begin{aligned}
& \text { E2 }=\left[\Sigma\left(E^{*} T C_{8}\right)\right] *\left(W_{P L A}^{*} .25\right) \text {, } \\
& \text { where, } \\
& \text { E = Leaf transpiration }\left(\mathrm{mmol} \mathrm{m}^{-2} \mathrm{~s}^{-1}\right) \text { on the sun- } \\
& \text { exposed aspect of the canopy, } \\
& \text { TC. = Transpiration coefficient within shade layer } \mathrm{s} \\
& \text { (for } \mathrm{s}=1 \ldots \mathrm{n}, 1=\mathrm{L} 1,2=\mathrm{L} 2,3=\mathrm{L} 3 \text {, and } 4=\mathrm{L} 4 \text { ), and } \\
& \text { WPLA }=\text { Whole plant leaf area }\left(\mathrm{m}^{2}\right. \text {; includes both leaf } \\
& \text { sides). }
\end{aligned}
$$

\section{Statistical Analysis}

A one-way completely randomized analysis of variance (AOV) was used to evaluate 2 levels of root treatment (severing and control) as sources of variation of E during a particular HPS and date. A repeated measures AOV was used to evaluate effects of root treatment and date as sources of variation of average daily $E$, average daily A, predawn leaf $\Psi$, WPLA, and WPE (Steel and Torrie 1980). Prior to each analysis, within-tree subsamples were pooled so that $n=3$ (trees) per root treatment. Average daily $E$ and $A$ were determined by averaging $E$ or $A$ values from 1-11 HPS (1986) and 2-12 HPS (1987).

\section{Results}

\section{Precipitation}

Monthly precipitation was much less from October to March, prior to the 1986 mesquite growing season, than prior to the 1987 growing season, when precipitation was above normal (Fig. 1). During the mesquite growing season, precipitation was above normal in April and May 1986 and well above amounts which occurred during the same 2 months in 1987. Precipitation was above normal in June and near or below normal from July through September in both years.

\section{Mesquite Phenology}

Mesquite budbreak occurred on root-severed and control trees in mid-March 1986. Leaves were fully expanded by the last week in April. In 1987, budbreak did not occur until mid-April, and leaves were not fully expanded until mid-May on trees in both treatments. Leaf abscission from frost occurred on all trees in mid-November during both years.

\section{Leaf Transpiration}

Transpiration of sun-exposed leaves (E) on control trees displayed maximum values at 7 hours post sunrise (HPS) in April and September, and earlier in the day ( 1 or 3 HPS) from 21 May through 12 August 1986 (Fig. 2). E was similar in root-severed and control trees from April through June 1986, but was significantly greater in root-severed trees than control trees at most HPS from July through September. E was similar in both treatments during 1987.

Average daily transpiration of sun-exposed leaves (average daily E) was similar between treatments from April through June 1986, but was significantly greater (range of 38 to 53\%) in root-severed than control trees from July through September (Fig. 3 a). There

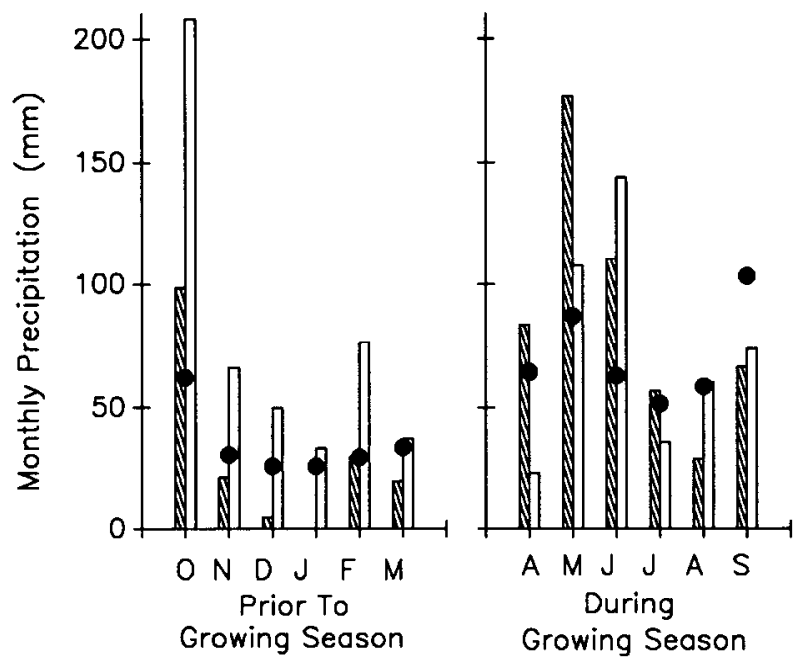

Fig. 1. Monthly precipitation totals at the study area near Throckmorton, Texas, during months prior to and during the mesquite growing season. Hatched bars: prior to 1986 growing season (left) and during the 1986 growing season (right). Open bars: prior to 1987 growing season (left) and during the 1987 growing season (right). Solid circles indicate 30 year average for each month obtained from National Oceanic and Atmospheric Administration (NOAA) records at a station $15 \mathrm{~km}$ from the research site.

were no significant differences in average daily $E$ between treatments in 1987 (Fig. 3b). Average daily $\mathbf{E}$ of control trees tended to be greater on comparable dates in 1986 than 1987 (Fig. $3 \mathrm{a}-\mathrm{b}$ ).

\section{Whole Plant Leaf Area}

On 12 June 1986, whole plant leaf area (WPLA) was similar between treatments (Fig. 3 c). WPLA decreased slightly (7\%) in control trees from 12 June to 23 July 1986. During the same interval, WPLA decreased by $50 \%$ in root-severed trees to levels which were significantly lower than those of control trees. The abscission of leaves on root-severed trees occurred very rapidly within a 4 to 6 day interval during the first week of July. Rootsevered trees appeared to replace little leaf area during the rest of the 1986 growing season, although this was not measured.

During 1987, WPLA decreased in both treatments from 11 May to 7 August. The decrease was slightly more in root-severed than control trees. However, no significant differences in WPLA were found between treatments in 1987, (Fig. 3d).

\section{Daily Whole Plant Transpiration}

Daily whole plant transpiration (WPE) was similar between treatments on all sample dates in 1986 (Fig. 3 e). From April to June 1986, similarities in WPE between treatments occurred because of similar average daily $E$ and WPLA values between treatments (Fig. $3 \mathrm{a}, \mathrm{c}$ ). Following differential reduction in WPLA between root-severed and control trees in early July 1986, E of remaining leaves on root-severed trees increased relative to control trees, producing similar WPE values between treatments from July to September 1986, although WPE was slightly, but not significantly, lower in root-severed than control trees toward the end of the 1986 growing season (Fig. $3 \mathrm{a}, \mathrm{c}, \mathrm{e}$ ). WPE was similar in rootsevered and control trees on all dates in 1987 (Fig. $3 \mathrm{f}$ ).

\section{Predawn leaf $\Psi$ and Photosynthesis}

Predawn leaf $\Psi$ was significantly less in root-severed than control trees in June 1986 (Fig. 4). Following a decline in both treatments during July, predawn leaf $\Psi$ was significantly greater in root-severed than control trees in August 1986. There were no 


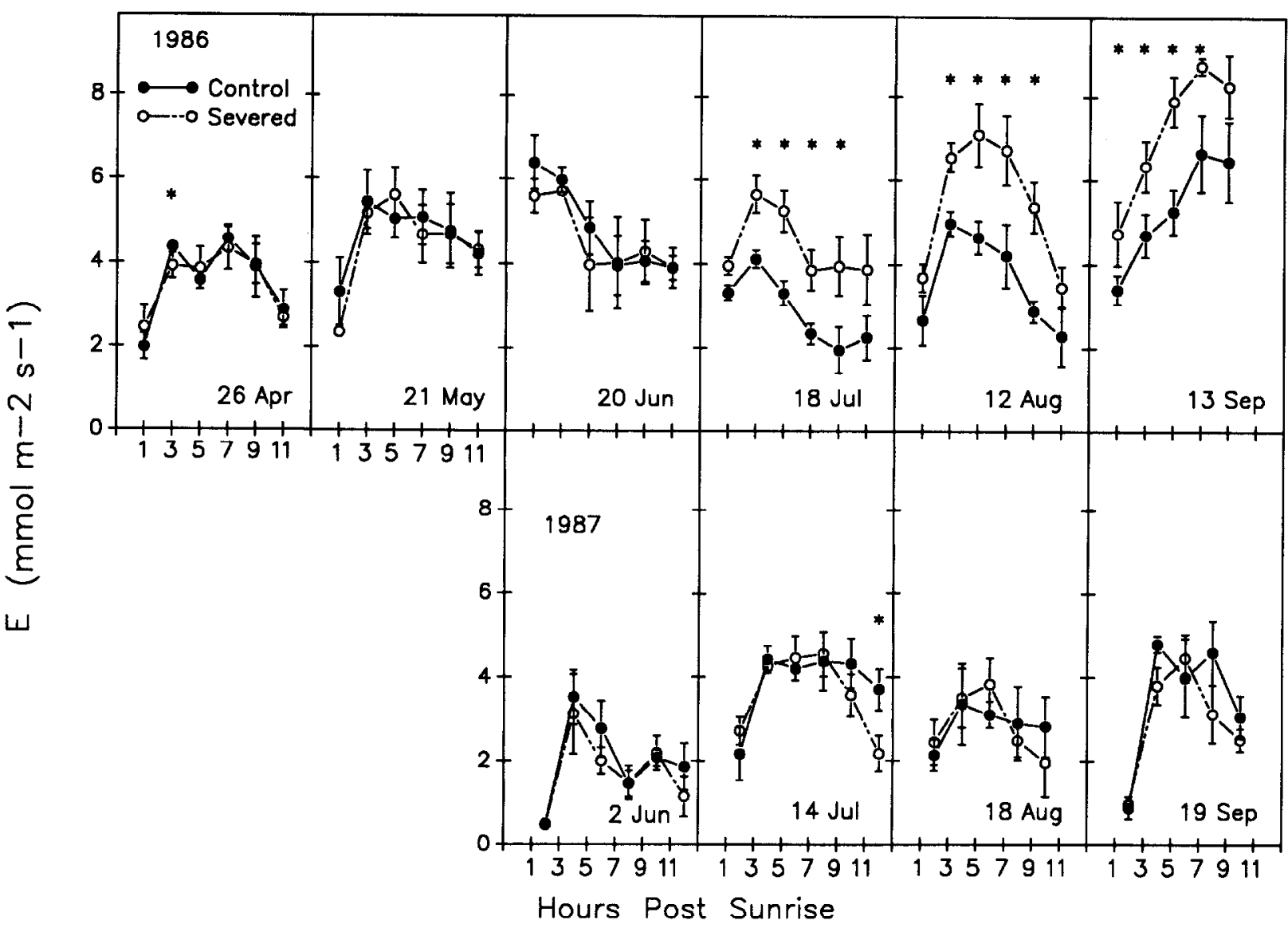

Fig. 2. Diurnal leaf transpiration (E) on control and root-severed mesquite on several dates in 1986 and 1987 . An asterisk identifies a significant difference between the root treatments at a particular hour post sunrise $(P \leq .05)$. Vertical bars indicate \pm 1 standard error.

significant differences in predawn leaf $\Psi$ between treatments in 1987.

Average daily leaf photosynthesis (average daily A) was similar between treatments in May and June 1986, but was significantly greater (range of 34 to $48 \%$ ) in root-severed than control trees from July through September (Fig. 4). Average daily A was similar between treatments in 1987 except in early June and September when it was slightly (but not significantly) lower in root-severed than control trees.

\section{Discussion}

\section{Estimation of Whole Plant Transpiration}

Results from this study indicated mesquite water loss ranged from 1.7 to $4.2 \mathrm{kmol}^{-1} \mathrm{drey}^{-1}$, or 30 to 75 liters tree $\mathrm{day}^{-1}$ ). In his book, Larcher (1975) noted that the average loss of water per day of a birch (Betula spp.) tree on a sunny summer day was about 100 liters. Schultze et al. (1985) estimated daily transpiration of coniferous trees Picia abies and Larix spp. to be 75 and 63 liters per day, as measured by a discontinuous gas exchange porometer and extrapolated over total canopy area. Water use by phreatophytic honey mesquite in the Sonoran desert of California was estimated at 12,000 liters per year (Nilsen et al. 1983, Jarrell et al. 1990), which we estimated to be about 56 liters per day, based on an April-October growing season (214 days). In summary, estimates of WPE in our study appear to be compatible with other studies, although our maximum WPE values were higher than that previously reported for mesquite.

\section{Leaf and Whole Plant Responses}

The data suggest that moisture stress in root-severed mesquite was no greater than in control trees during the first part of the 1986 growing season, April through mid-June, when precipitation was well above normal. The onset of stress in root-severed trees appeared to be very acute, occurring in late June when predawn leaf $\Psi$ was significantly lower in these trees than in control trees. The response to alleviate stress was also rapid. All defoliation in root-severed trees occurred within about 4-6 days in early July, about 2 weeks after differential stress between treatments was first detected.

Leaf abscission during the growing season is generally the result of moisture stress (Kozlowski 1976). Abscission in root-severed mesquite was likely an adjustment to compensate for an imbalance between transpirational surface area and ability of remaining unsevered roots to provide sufficient water. Kaufmann and Fiscus (1985) discussed the hypothesis that plants attempt to maintain a balance between leaf area and absorbing area of fine roots. However, unlike predawn leaf $\Psi$, other leaf variables we measured, such as $E$ and $A$, were not different between control and root-severed trees prior to abscission in root-severed trees. Thus, leaf responses did not clearly indicate that root-severed trees were stressed prior to leaf shedding.

While many studies have demonstrated that stomata respond directly to stimuli from the microenvironment near the leaf (Cowan 1977, Farquhar and Sharkey 1982, Spence et al. 1983), reduction in leaf area, as found in root-severed but not unsevered mesquite in 1986, suggests the presence of a root-system based regulation of water loss which outweighed responses of individual leaves to leaf microenvironment. Research by others has demonstrated that root systems of drought-stressed plants signal leaves via abscisic acid (ABA) which is produced in the roots and transported to the leaves where it may influence either stomatal closure or abscission (Cornish and Zeevaart 1985, Zhang et al. 1987). This 

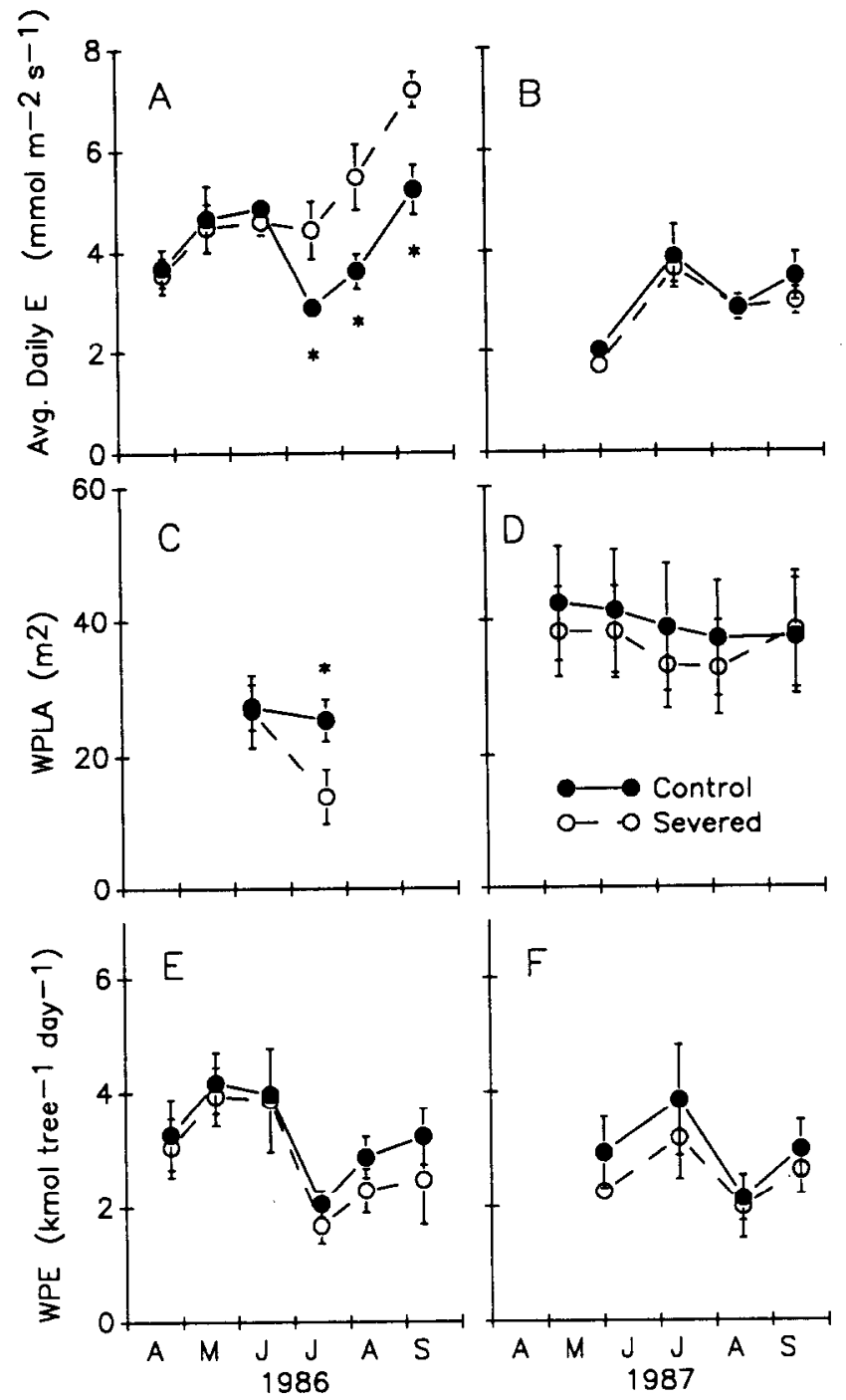

Fig. 3. Average daily leaf transpiration (Average daily E, top), whole plant leaf area (middle), and daily whole plant transpiration (WPE, bottom) of control (solid line) and root-severed (dashed line) mesquite at Spade Wagon Creek. Values for WPLA and WPE were determined using both leaf sides. An asterisk indicates a significant difference $(P<0.05)$ between treatments on a particular date. Vertical bars indicate \pm 1 standard error.

process may have caused leaf abscission in root-severed mesquite, although measurements of $\mathrm{ABA}$ were not conducted. The rapidity of abscission in mesquite (occurring within 4-6 days) is in agreement with the ABA studies which indicated that following root sensation of soil drought, ABA production in roots, as well as responses of leaves to root-produced ABA, were rapid.

Following abscission, increases in $\mathrm{A}$ and $\mathrm{E}$ of remaining leaves on root-severed mesquite relative to control trees were similar to responses of remaining leaves of some grasses (Painter and Detling 1981, McNaughton 1983, Nowak and Caldwell 1984) and trees (Heichel and Turner 1983) following partial defoliation. Black and Mack (1986) found an increase in $E$ of remaining leaves on big sagebrush (Artemisia tridentata) following leaf abscission during summer drought. The increases in $A$ and $E$ found in these studies may have been necessary to facilitate compensatory leaf growth. Detling et al. (1979) reported an increase in the proportion of current photosynthate allocated to synthesis of new leaves following defoliation of blue grama (Bouteloua gracilis). Conversely, McNaughton (1983) suggested that defoliation may conserve soil water and thereby improve water status of remaining leaves.
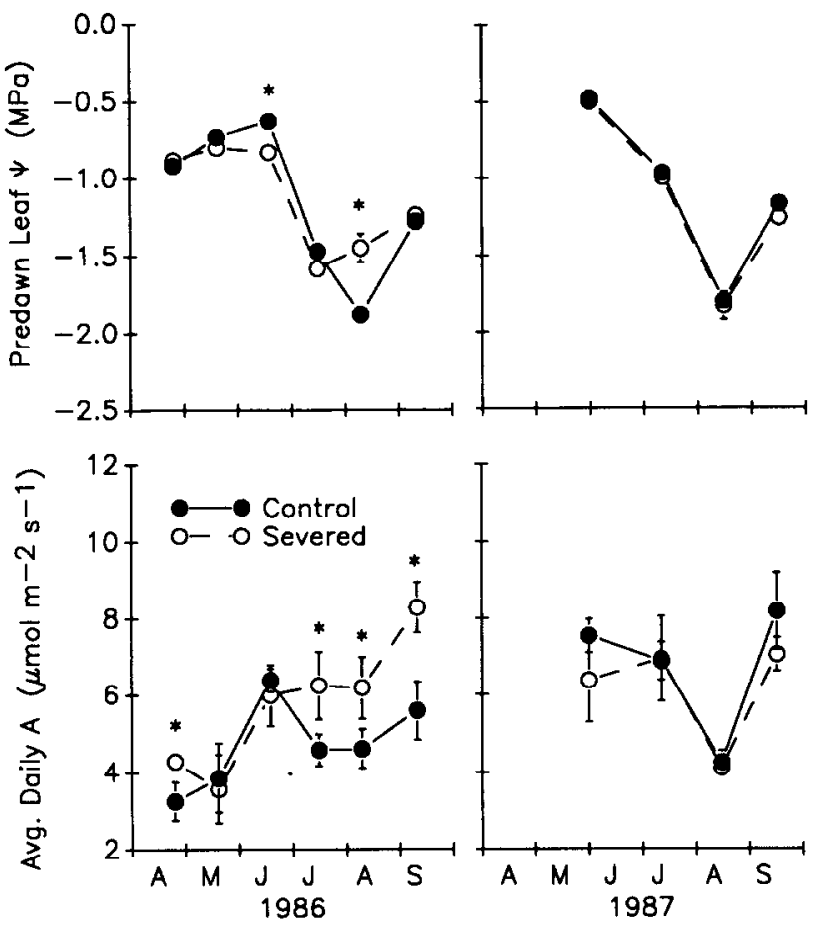

Fig. 4. Predawn leaf water potential (top) and average daily leaf photosynthesis (average daily $A$, bottom) of control (solid line) and root-severed (dashed line) trees at Spade Wagon Creek. An asterisk indicates a significant difference $(P<0.05)$ between treatments on a particular date. Vertical bars are \pm 1 standard error.

Post-abscission responses by root-severed mesquite were similar to those of red oak (Quercus rubra) and red maple (Acer rubrum) in a study reported by Heichel and Turner (1983). These species replaced little leaf area following $50 \%$ defoliation, although remaining leaves had 54 and $75 \%$ increases in $A$, and 46 and $36 \%$ increases in stomatal conductance, respectively, when compared to undefoliated control trees.

Since we did not observe compensatory leaf growth on defoliated mesquite, the increased $\mathrm{A}$ and $\mathrm{E}$ following abscission may have been necessary for compensatory root growth. Several studies have reported increased $A$ and $E$ in leaves, as well as growth of new roots, following root pruning (Geisler and Ferree 1984, Ruff et al. 1987, Crombie et al. 1987). Richards and Rowe (1977) observed a redistribution of assimilates to roots following root pruning of peach (Prunus persica).

It is not known, if, when, or to what degree compensatory root growth occurred in mesquite. However, the absence of differential abscission between treatments in 1987 suggests root-severed trees had adjusted to the containerized environment by the second year of the study. These results are similar to those found by Ansley et al. (1990) in which reduction of stomatal conductance in rootsevered trees was found during the first year following lateral root severing but not during the second growing season. These studies illustrate a previously undocumented aspect of the tremendous plasticity of this invasive woody plant in the way of root system recovery following severe manipulation.

\section{Lateral Root Dependence}

Honey mesquite exhibit phreatophytic behavior in some regions, such as the Sonoran desert of southern California (Mooney et al. 1977 , Nilsen et al. 1984). This is attributed to the plant's ability to acquire an abundant supply of water via a deep taproot (Phillips 1963, Jarrell et al. 1990). Aboveground responses associated with this behavior include a relatively constant seasonal pattern of leaf 
transpiration and maintenance of maximum canopy leaf area (Nilsen et al. 1983). Under these circumstances, regulation of water loss by the plant may be secondarily important to water acquisition. In contrast, results from our study, and from a similar study by Ansley et al. (1990), imply that on certain sites mesquite may not have a well-developed taproot and may depend primarily on lateral roots for water acquisition, thereby magnifying the importance of canopy regulation of water loss.

Results from the current study and the study by Ansley et al. (1990), which was conducted on 2 sites $60 \mathrm{~km}$ from the current study area, illustrate a variety of responses of mesquite to severing of lateral roots. On 1 site reported by Ansley et al. (1990), stomatal conductance was significantly reduced in root-severed trees when compared to unsevered control trees. On the second site reported in their study, stomatal conductance was only slightly reduced in root-severed trees. Plant leaf area was not affected by lateral root severing on either site. In the present study, leaf abscission in response to later root severing indicated an extreme dependence on lateral roots. The importance of these roots is elevated further when considering that precipitation was well above normal during April through June 1986 (Fig. 1), yet abscission still occurred. These studies suggest that as dependence on lateral roots increased among sites, response to severing of these roots proceeded from a slight reduction in stomatal conductance, to substantial stomatal regulation of water loss, and finally leaf abscission. Degree of dependence on lateral roots may relate to subsoil characteristics on a particular site (Ansley et al. 1990). Results from these studies indicate that strategies for regulation of water loss by this invasive woody plant vary with site and may involve a combination of stomatal control and adjustment of transpirational surface area.

\section{Literature Cited}

Ansley, R.J., D.L. Price, B.K. Lawrence, and P.W. Jacoby. 1988. A truck-mounted mobile screen for photodigital estimation of whole plant leaf area. J. Range Manage. 41:355-358.

Ansley, R.J., P.W. Jacoby, and B.K. Lawrence. 1989. Influence of stress history on water use patterns of honey mesquite, p. 75-82. In: Proc. Symp. on Shrub Ecophysiology and Biotechnology (eds. A. Wallace, E.D. McArthur, M.R. Haferkamp), 30 June-2 July 1987, Logan, Utah; Gen. Tech. Rep. INT-256, USDA Forest Serv. Intermtn. Res. Sta. Ogden, Utah.

Ansley, R.J., P.W. Jacoby, and G.J. Cuomo. 1990. Water relations of honey mesquite following severing of lateral roots: Influence of location and amount of subsurface water. J. Range Manage. 43:436-442.

Black, R.A., and R.N. Mack. 1986. Mount St. Helens ash: Recreating its effects on the steppe environment and ecophysiology. Ecology 67:1289-1302.

Caldwell, M.M., H.P. Meister, J.D. Tenhunen, and O.L. Lange. 1986. Canopy structure, light microclimate and leaf gas exchange of Quercus coccifera L. in a Portuguese macchia: Measurements in different canopy layers and simulations with a canopy model. Trees 1:25-41.

Cornish, K., and J.A.D. Zeevaart. 1985. Abscisic acid accumulation by roots of Xanthium strumarium L. and Lycopersicon esculentum Mill. in relation to water stress. Plant Physiol. 79:653-658.

Cowan, I.R. 1977. Stomatal behavior and environment. Adv. Bot. Res. 4:117-228.

Crombie, D.S., J.T. Tippett, and D.J. Goddard. 1987. Water relations of root-pruned jarrah (Eucalyptus marginata Donn ex. Smith) saplings. Aust. J. Bot. 35:653-663.

Detling, J.K., M.I. Dyer, and D. Winn. 1979. Net photosynthesis, root respiration, and regrowth of Bouteloua gracilis following simulated grazing. Oecologia 41:127-134.

Farquhar, G.D., and T.D. Sharkey. 1982. Stomatal conductance and photosynthesis. Annu. Rev. Plant Physiol. 33:317-345.

Geisler, D., and D.C. Ferree. 1984. The influence of root pruning on water relations, net photosynthesis and growth of young 'Golden Delicious' apple trees. J. Amer. Soc. Hort. Sci. 109:827-831.

Gold, W.G., and M.M. Caldwell. 1989. The effects of spatial pattern of defoliation on regrowth of a tussock grass. II. Canopy gas exchange. Oecologia 81:437-442.
Heichel, G.H., and N.C. Turmer. 1983. $\mathrm{CO}_{2}$ assimilation of primary and regrowth foliage of red maple (Acer rubrum L.) and red oak (Quercus rubra L.): Response to defoliation. Oecologia 57:14-19.

Heitschmidt, R.K., R.J. Ansley, S.L. Dowhower, P.W. Jacoby, and D.L. Price. 1988. Some observations from the excavation of honey mesquite root systems. J. Range Manage. 41:227-231.

Hinckley, T.M., and R. Ceulemans. 1989. Current focuses in woody plant water relations and drought resistance. Ann. Sci. For. 46:317-324.

Jarrell, W.M., and R.A. Virginia. 1990. Soil cation accumulation in a mesquite woodland: sustained production and long-term estimates of water use and nitrogen fixation. J. Arid Environ. 18:51-58.

Kaufmann, M.R., and E.L. Fiscus. 1985. Water transport through plants: Internal integration of edaphic and atmospheric effects. Acta Hort. 171:83-93.

Kozlowski, T.T. 1976. Water supply and leaf shedding, p. 191-231. In: Water deficits and plant growth, Vol. 4 (ed. T.T. Kozlowski), Academic Press, N.Y.

Landsberg, J.J., and R. McMurtrie. 1984. Water use by isolated trees. Agr. Water Manage. 8:223-242

Larcher, W. 1975. Physiological plant ecology. Springer-Verlag, N. Y.

Levitt, J. 1980. Responses of plants to environmental stresses. Academic Press, N.Y.

Ludwig, J.A. 1977. Distributional adaptions of root systems in desert environments, p. 85-91. In: The belowground ecosystem: A synthesis of plant-associated processes (ed. J.K. Marshall), Range Science Dept., Colorado State Univ. Series 26, Fort Collins, Colo.

McNaughton, S.J. 1983. Compensatory plant growth as a response to herbivory. Oikos 40:329-336.

Meinzer, F.C., M.R. Sharifi, E.T. Nilsen, and P.W. Rundel. 1988. Effects of manipuation of water and nitrogen regime on the water relations of the desert shrub Larrea tridentata. Oecologia 77:480-486.

Mooney, H.A., B.B. Simpson, and O.T. Solbrig. 1977. Phenology, morphology, physiology. Chap. 2, p. 26-41. In: Mesquite-Its biology in two desert ecosystems (ed. B.B. Simpson). US/IBP Synthesis Series 4. Dowden, Hutchinson and Ross, Inc., Stroudsburg, Pa.

Nilsen, E.T., P.W. Rundel, and M.R. Sharifi. 1981. Summer water relations of the desert phreatophyte Prosopis glandulosa in the Sonoran desert of Southern California. Oecologia 50:271-276.

Nilsen, E.T., M.R. Sharifi, P.W. Rundel, W.M. Jarrell, and R.A. Virginia. 1983. Diurnal and seasonal water relations of the desert phreatophyte Prosopis glandulosa (honey mesquite) in the Sonoran desert of California. Ecology 64:1381-1393.

Nilsen, E.T., M.R. Sharifi, and P.W. Rundel. 1984. Comparative water relations of phreatophytes in the Sonoran desert of California. Ecology 65:767-778.

Nilsen, E.T., M.R. Sharifi, and P.W. Rundel. 1987. Leaf dynamics in an evergreen and a deciduous species with even-aged leaf cohorts, from different environments. Amer. Midl. Natur. 118:46-55.

Nowak, R.S., and M.M. Caldwell. 1984. A test of compensatory photosynthesis in the field: implications for herbivory tolerance. Oecologia 61:311-318.

Painter, E.L., and J.K. Detling. 1981. Effects of defoliation on net photosynthesis and regrowth of western wheatgrass. J. Range Manage. 34:68-71.

Phillips, W.S. 1963. Depth of roots in soil. Ecology 44:424.

Pook, E.W. 1985. Canopy dynamics of Eucalyptus maculata Hook. III. Effects of drought. Aust. J. Bot. 33:65-79.

Raupach, M.R., and J.J. Finnigan. 1988. 'Single layer models of evaporation from plant canopies are incorrect but useful, whereas multilayer models are correct but useless':Discuss. Aust. J. Plant Physiol. 15:705-716.

Richards, D., and R.N. Rowe. 1977. Root-shoot interactions in peach: The function of the root. Ann. Bot. 41:1211-1216.

Ruff, M.S., D.T. Krizek, R.M. Mirecki, and D.W. Inouye. 1987. Restricted root zone volume: Influence on growth and development of tomato. J. Amer. Soc. Hort. Sci. 112:763-769.

Schulze, E.-D., and A.E. Hall. 1982. Stomatal responses, water loss and $\mathrm{CO}_{2}$ assimiltion rates of plants in contrasting environments. Chap. 7, p. 181-224. In: Physiological plant ecology II, Vol. 12B(eds. O.L. Lange et al.), Encyclop. Plant Physiol., Springer-Verlag, Berlin.

Schulze, E.-D., A.E. Hall, O.L. Lange, and H. Walz. 1982. A portable steady-state porometer for measuring the carbon dioxide and water vapor exchanges of leaves under natural conditions. Oecologia 53:141-145. 
Schulze, E.D., J. Cermak, R. Matyssek, M. Penka, R. Zimmermann, F. Vasicek, W. Gries, and J. Kucera. 1985. Canopy transpiration and water fluxes in the xylem of the trunk of Larix and Picea trees-a comparison of xylem flow, porometer, and cuvette measurements. Oecologia 66:475483.

Spence, R.D., P.J.H. Sharpe, R.D. Powell, and C.A. Rogers. 1983. Epidermal and guard cell interactions on stomatal aperture in epidermal strips and intack leaves. Ann. Bot. 5:1-12.

Steel, R.G.D., and J.H. Torrie. 1980. Principles and procedures of statistics: a biometrical approach. 2nd. edit., McGraw-Hill Co., New York, N.Y.
Thomas, G.W., and R.E. Sosebee. 1978. Water relations of honey mesquite-a facultative phreatophyte, p. 414-418 In: Proc. Ist Int. Rangeland Congress (ed. D.N. Hyer), Soc. Range Manage. Denver, Colo.

Turner, N.C. 1981. Techniques and experimental approaches for the measurement of plant water status. Plant and Soil 58:339-366.

Zhang, J., U.Schurr, and W.J. Davies. 1987. Control of stomatal behavior by abscisic acid which apparently originates in the roots. J. Exp. Bot. 38:1174-1181. 